\title{
Nutritional Composition and Functional Properties of a Fortified Ivorian Local Food "BASSI" of Maize
}

\author{
Niaba Koffi Pierre Valery ${ }^{1,3}$, COMBO Agnan Marie-Michel ${ }^{3}$, \\ Deffan Zranseu Ange Benedicte ${ }^{3}$, Marina C. Kouakou ${ }^{4}$, \\ Germain A. Brou' ${ }^{2}$, Gildas K. Gbassi ${ }^{1,2}$
}

\begin{abstract}
${ }^{1}$ Food, Water and Beverage Control Service, National Laboratory of Public Health (LNSP), BP 2403 Abidjan 18, Côte d'Ivoire ${ }^{2}$ Department of Analytical Chemistry, General and Mineral Chemistry, UFR Pharmaceutical and Biological Sciences, Félix Houphouët Boigny University, BPV 34 Abidjan 01, Cote d'Ivoire

${ }^{3}$ Agro-valorization Laboratory, Agro forestry Department, Jean Lorougnon Guédé University, Daloa, Côte d'Ivoire, BP 150

${ }^{4}$ Nutrition and Food Security Laboratory, Nagui Abrogoua University, Abidjan, Côte d'Ivoire
\end{abstract}

\begin{abstract}
Six (6) formulations of "BASSI" based on a mixture of maize and soybeans have been developed. Soy flour was incorporated in amounts of $0,10,20,30,40$ and $50 \%$. The results showed that the nutritional value significantly increases with the incorporated soy rate, except the carbohydrate content which decreases. The water absorption capacity, oil absorption capacity and emulsifying activity also increased. As for the emulsion stability and the bulk density, the values decrease. The incorporation of soy improves the nutritional and functional properties of "BASSI".
\end{abstract}

Keywords: "BASSI", Cereal-Based Food, Chemical Composition, Functional Properties

\section{Introduction}

Dietary deficiencies are major scourges news. According to FAO, more than one billion people are affected by malnutrition in worldwide, most of which is in developing countries (FAO, 2009). The main causes are a protein-energy food deficit and a deficiency of certain key micronutrients such as calcium, iron and zinc (Soro et al., 2013). But we should add the unsustainable and inequitable access to food by the most vulnerable social strata and also the bad nutritional practices. Grains, including maize and millet are the staple food of many populations around the world. In Cote d'Ivoire, maize is the second cereal most cultivated and consumed after rice (Akanvou et al., 2006), while millet is the 3rd (Békoye and Akanvou, 2005). These food crops are used in the manufacture of many traditional dishes, including "BASSI". This multicultural food made from local product is consumed by the Ivorian population and several countries of the subregion. It is obtained after cooking cornmeal or millet and added sugar. But its nutritional value seems to be unbalanced because the main raw materials (maize and millet) for the manufacture of this commodity are rich in carbohydrates and low in proteins. The levels are $73 \%$ and $9.2 \%$ for maize and $67 \%$ and $11.8 \%$ for millet respectively (FAO, 1995). Generally, grains have low protein concentration and the quality of

\begin{abstract}
these proteins is limited by deficiencies in certain essential amino acids. Thus, it is necessary to incorporate a product with high nutritional density, and soy appears to meet this requirement. In most developing countries, soybean cultivation is encouraged. This legume is known for its seeds rich in protein $(40 \%)$ and fat $(20 \%)$, giving him the rank of first oleaginous-protein cultivated in the world (Duc et al., 2010). According to Zannou-Tchoko et al. (2011), soybean contains in balanced proportions proteins of good biological value with all essential amino acids. It also contains fatty acids such as omega (Demaison and Moreau, 2002). In addition to provide essential nutrients, it is used for its excellent functional properties in improving food processes (Wolf, 1970). Several formulations of "BASSI" from maize with soybeans incorporating were developed with the objective to determine the chemical composition of such mixtures; and assess their functional properties.
\end{abstract}

\section{Materials and Methods}

\subsection{Materials}

The plant material used was white maize (Zea mays) and yellow soybeans (Glycine max).

This article is published under the terms of the Creative Commons Attribution License 4.0 Author(s) retain the copyright of this article. Publication rights with Alkhaer Publications. Published at: http://www.ijsciences.com/pub/issue/2020-07/

DOI: 10.18483/ijSci.2358; Online ISSN: 2305-3925; Print ISSN: 2410-4477 


\subsection{Methods}

\subsubsection{Formulations of "BASSI" improved with} soybean

Six formulations of "BASSI" containing soybean have been developed, six from maize. Soy flour was mixed with that of maize (AF) in the following proportions: $0 \%$ (AF0), 10\% (AF1), 20\% (AF2), 30\% (AF3), 40\% (AF4) and 50\% (AF5). $25 \mathrm{~g}$ of sugar were added to $100 \mathrm{~g}$ of each mixture of flour. A specific volume of water was added to each mixture. The preparation process of "BASSI" is presented in figure 1 .

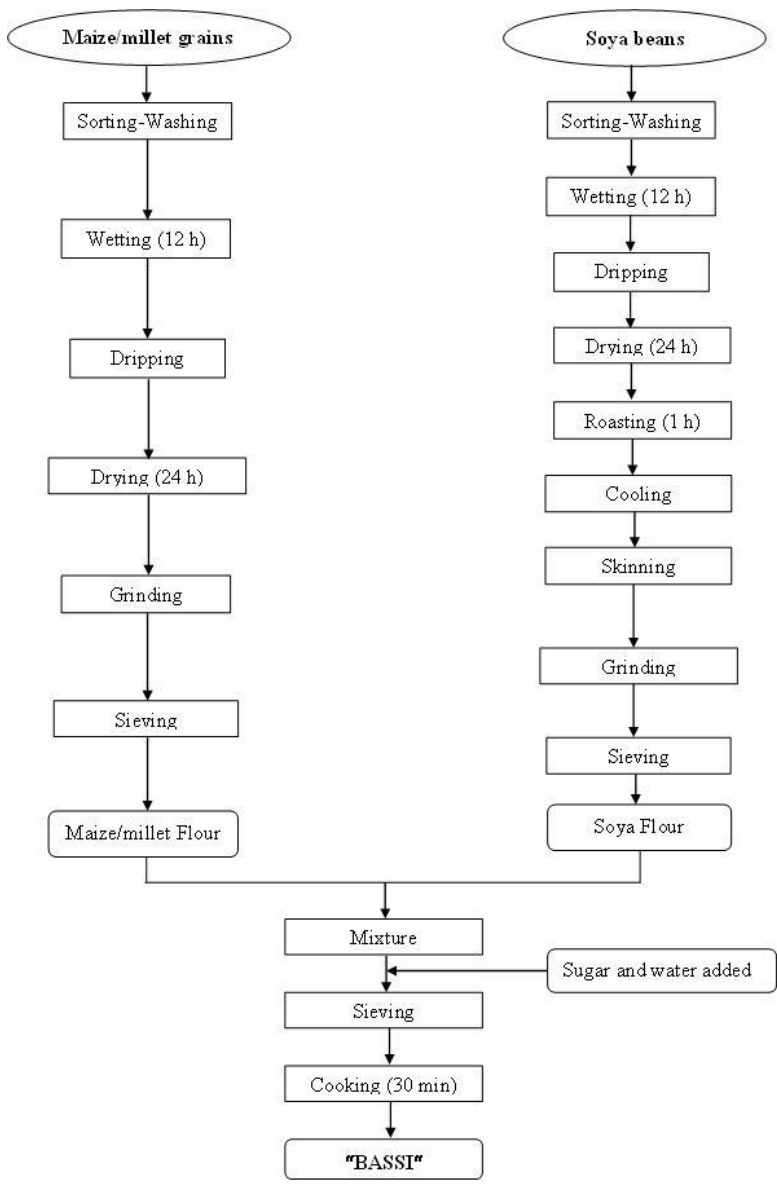

Figure 1: Scheme of "BASSI" manufacturing improved with soybean
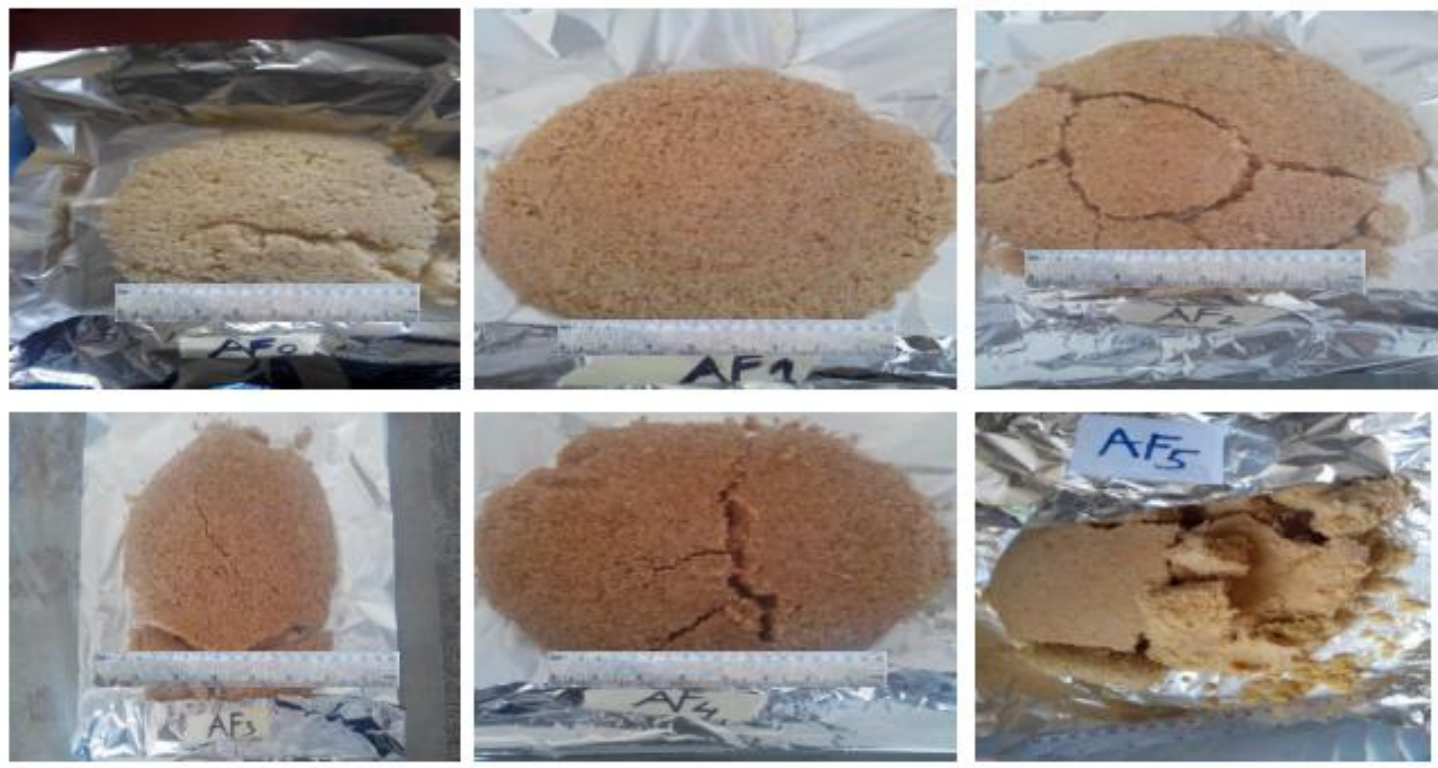

Photocopy: "BASSI" improved with soybean

2.2.2. Chemical analysis of "BASSI" improved with soybean

Water content and ashes content were determined according to an official method (AOAC, 1990).
Moisture was determined by drying in an oven at 105 ${ }^{\circ} \mathrm{C}$ for 24 hours and ash using a muffle furnace at 550

${ }^{\circ} \mathrm{C}$ for $24 \mathrm{~h}$. Proteins were quantified according to AOAC (1990) using the Kjeldahl method which 
taking place in three steps namely mineralization, distillation and acid-base quantification. Fat content was determined according to the method of Folch et al. (1957) using vacuum filtration and a solvent combination (chloroform and methanol) to extract the fat. Total carbohydrate was determined by difference of the total material to other biochemical compounds. Energy value corresponding to the available energy was calculated using the specific coefficients of Atwater and Benedict (1902) for proteins, lipids and carbohydrates. The $\mathrm{pH}$ and total acidity were determined according to AOAC (1990). For the last two parameters, each sample was diluted in $100 \mathrm{ml}$ of distilled water, stirred for $30 \mathrm{~min}$ and the resulting mixture was filtered before analysis.

\subsubsection{Functional properties of "BASSI"}

The water absorption capacity (WAC) was determined using the method of Phillips et al. (1988). The oil absorption capacity (OAC) was determined according to the method of Sosulski (1962). The hydrophilic-lipophilic index (HLI) as defined by Njintang et al. (2001) was calculated as the ratio of WAC/OAC. The emulsifying activity (EA) and emulsion stability (ES) were determined by the method of Yasumatsu et al. (1972). The bulk density (BD) was determined according to the method of Narayana and Narasimga (1982).

\subsubsection{Statistical data processing}

All measurements were performed in triplicate. Statistical differences were verified by ANOVA with SPSS 19.0 software. The comparison of means was carried out with the Duncan test for a significance level set at $5 \%$.

\section{Results and Discussion \\ 3.1. Results}

\subsubsection{Chemical analysis of "BASSI" improved} with soybean

3.1.1.1. Case of "BASSI" based maize

The nutritional composition of all formulations is presented in table 1. Water content is between $4.05 \pm$ 0.01 and $4.74 \pm 0.09 \mathrm{~g} / 100 \mathrm{~g}$ of dry matter (DM). Protein, fat and ash increases with incorporated soy rate. Values are significantly different $(\mathrm{p}<0.05)$ and range from $6.53 \pm 0.01$ to $22.33 \pm 0.01$ for proteins, $3.08 \pm 0.02$ to $9.23 \pm 002$ for fat and $0.62 \pm 0.00$ to $2.40 \pm 0.01$ for ashes. The mineral composition gradually increases with the incorporation of soy. Macro-minerals such as calcium, phosphorus, potassium, magnesium and sodium increase significantly ( $\mathrm{p}<0.05)$. Trace elements like manganese, iron, copper and zinc also significantly increase with incorporated soy rate $(\mathrm{p}<0.05)$. On the other side, total carbohydrate content decreases ( $p$ $<0.05)$. Incorporation of soybean also improves the energy value of the formulations $(\mathrm{p}<0.05)$. The results for the sugar content, $\mathrm{pH}$ and acidity are presented in table 2. Total sugar content decreases gradually as soybean increases. Values range between $16.75 \pm 0.17$ and $14.01 \pm 0.91 \mathrm{mg} / \mathrm{ml}$. pH and acidity changing inversely as soybean increases. The $\mathrm{pH}$ values are significantly different $(\mathrm{p}<0.05)$. Acidity is statistically identical with 10 to $40 \%$ of incorporated soybean but different with 0 and $50 \%$ of incorporated soybean $(\mathrm{p}<0.05)$.

Table 1: Nutritional value of "BASSI" based maize improved with soybean

\begin{tabular}{|c|c|c|c|c|c|c|}
\hline \multirow[t]{2}{*}{ Parameters } & \multicolumn{6}{|c|}{ Content (g/100 g of dry matter) } \\
\hline & AF0 & AF1 & AF2 & AF3 & AF4 & AF5 \\
\hline Moisture & $4.05^{a} \pm 0.01$ & $4.09^{\mathrm{ab}} \pm 0.02$ & $4.12^{\mathrm{ab}} \pm 0.05$ & $4.26^{c} \pm 0.04$ & $4.74^{\mathrm{d}} \pm 0.09$ & $4.16^{\mathrm{b}} \pm 0.05$ \\
\hline Proteins & $6.53^{a} \pm 0.01$ & $7.72^{b} \pm 0.01$ & $10.91^{\mathrm{c}} \pm 0.02$ & $15.74^{\mathrm{d}} \pm 0.03$ & $19.06^{\mathrm{e}} \pm 0.03$ & $22.33^{\mathrm{f}} \pm 0.01$ \\
\hline Fat & $3.08^{a} \pm 0.02$ & $3.37^{b} \pm 0.02$ & $4.43^{c} \pm 0.02$ & $6.14^{\mathrm{d}} \pm 0.20$ & $7.21^{\mathrm{e}} \pm 0.15$ & $9.23^{\mathrm{f}} \pm 0.02$ \\
\hline Ashes & $0.62^{a} \pm 0.00$ & $1.09^{b} \pm 0.01$ & $1.43^{c} \pm 0.01$ & $1.81^{\mathrm{d}} \pm 0.00$ & $2.13^{\mathrm{e}} \pm 0.01$ & $2.40^{\mathrm{f}} \pm 0.01$ \\
\hline Carbohydrates & $85.72^{\mathrm{f}} \pm 0.03$ & $83.61^{\mathrm{e}} \pm 0.19$ & $79.14^{\mathrm{d}} \pm 0.07$ & $72.06^{c} \pm 0.19$ & $66.86^{\mathrm{b}} \pm 0.12$ & $61.88^{a} \pm 0.08$ \\
\hline $\begin{array}{c}\text { Energetic } \\
\text { value* }\end{array}$ & $396.74^{a} \pm 0.16$ & $395.63^{a} \pm 0.80$ & $400.04^{b} \pm 0.50$ & $406.45^{c} \pm 1.18$ & $408.54^{\mathrm{d}} \pm 0.30$ & $419.91^{\mathrm{e}} \pm 0.08$ \\
\hline Minerals & \multicolumn{6}{|c|}{ Content (mg/100 g of dry matter) } \\
\hline Calcium & $18.30^{\mathrm{a}} \pm 0.00$ & $26.07^{b} \pm 0.14$ & $29.59^{c} \pm 0.17$ & $33.84^{\mathrm{d}} \pm 0.13$ & $41.56^{\mathrm{e}} \pm 0.17$ & $51.47^{\mathrm{f}} \pm 0.30$ \\
\hline Phosphorus & $43.37^{\mathrm{a}} \pm 0.17$ & $71.51^{b} \pm 0.08$ & $100.46^{c} \pm 0.13$ & $137.61^{\mathrm{d}} \pm 0.88$ & $143.40^{\mathrm{e}} \pm 0.18$ & $160.02^{f} \pm 0.60$ \\
\hline Potassium & $1007.61^{\mathrm{a}} \pm 1.92$ & $1312.15^{b} \pm 0.05$ & $1376.89^{c} \pm 1.11$ & $1398.61^{d} \pm 0.35$ & $1424.31^{\mathrm{e}} \pm 2.10$ & $1475.31^{f} \pm 0.64$ \\
\hline Magnesium & $28.06^{\mathrm{a}} \pm 0.21$ & $43.52^{\mathrm{b}} \pm 0.90$ & $49.27^{c} \pm 1.03$ & $65.73^{\mathrm{d}} \pm 0.85$ & $79.22^{\mathrm{e}} \pm 0.26$ & $112.00^{\mathrm{f}} \pm 0.40$ \\
\hline Sodium & $50.32^{\mathrm{a}} \pm 0.15$ & $86.17^{\mathrm{b}} \pm 0.01$ & $98.64^{c} \pm 0.27$ & $104.21^{d} \pm 0.26$ & $117.30^{\mathrm{e}} \pm 0.48$ & $144.15^{\mathrm{f}} \pm 0.15$ \\
\hline Manganese & $0.28^{\mathrm{a}} \pm 0.00$ & $0.49^{\mathrm{b}} \pm 0.01$ & $0.72^{c} \pm 0.02$ & $1.08^{\mathrm{d}} \pm 0.05$ & $1.44^{e} \pm 0.10$ & $1.57^{\mathrm{f}} \pm 0.01$ \\
\hline Iron & $3.12^{\mathrm{a}} \pm 0.10$ & $3.16^{a} \pm 0.05$ & $3.67^{\mathrm{b}} \pm 0.01$ & $3.85^{\mathrm{c}} \pm 0.03$ & $5.74^{\mathrm{d}} \pm 0.09$ & $8.30^{\mathrm{e}} \pm 0.09$ \\
\hline Copper & $0.06^{a} \pm 0.00$ & $0.18^{a} \pm 0.02$ & $0.40^{\mathrm{b}} \pm 0.07$ & $0.68^{c} \pm 0.09$ & $1.31^{\mathrm{d}} \pm 0.14$ & $1.83^{\mathrm{e}} \pm 0.06$ \\
\hline Zinc & $0.46^{\mathrm{a}} \pm 0.01$ & $0.50^{\mathrm{a}} \pm 0.00$ & $0.58^{b} \pm 0.03$ & $0.68^{c} \pm 0.01$ & $0.91^{\mathrm{d}} \pm 0.03$ & $1.00^{\mathrm{e}} \pm 0.02$ \\
\hline
\end{tabular}

Values followed by different letters in a line are statistically different $(\alpha=0.05)$. Values represent the mean $\pm S D$ of three independent measurements $(n=3) *($ Kcal/100 g of dry matter $)$. 
Table 2: Total sugars, $\mathrm{pH}$ and acidity of "BASSI" based maize improved with soybean

\begin{tabular}{|c|cccccc|}
\hline Parameters & \multicolumn{1}{|c}{ AF0 } & AF1 & AF2 & AF3 & AF4 & AF5 \\
\hline Total sugars* & $16.75^{\mathrm{c}} \pm 0.17$ & $16.57^{\mathrm{bc}} \pm 0.23$ & $15.70^{\mathrm{b}} \pm 0.62$ & $15.72^{\mathrm{b}} \pm 0.25$ & $14.69^{\mathrm{a}} \pm 0.28$ & $14.01^{\mathrm{a}} \pm 0.91$ \\
$\mathrm{pH}$ & $5.34^{\mathrm{a}} \pm 0,00$ & $5.98^{\mathrm{b}} \pm 0,00$ & $6.14^{\mathrm{c}} \pm 0.40$ & $6.24^{\mathrm{d}} \pm 0.01$ & $6.33^{\mathrm{e}} \pm 0.01$ & $6.42^{\mathrm{f}} \pm 0.00$ \\
Acidity** & $3.00^{\mathrm{b}} \pm 0.00$ & $2.67^{\mathrm{ab}} \pm 0.57$ & $2.33^{\mathrm{ab}} \pm 0.57$ & $2.67^{\mathrm{b}} \pm 0.57$ & $2.33^{\mathrm{ab}^{\mathrm{b}} \pm 0.57}$ & $2.00^{\mathrm{a}} \pm 0.00$ \\
\hline
\end{tabular}

Values followed by different letters in a line are statistically different $(\alpha=0.05)$. Values represent the mean $\pm S D$ of three independent measurements $(n=3) *(m g / m l) * *(m e q-g / 100 \mathrm{~g}$ of dry matter $)$.

\subsubsection{Functional properties of "BASSI" improved with soybean}

3.1.2.1. Case of "BASSI" based maize

The results for functional properties are presented in table 3. The WAC, OAC and EA increase with incorporated soybean rate. Values are significantly different $(p<0.05)$. As for the ES, the values decrease, the formulations with 10 to $40 \%$ of soybean
(AF1 to AF4) are statistically different from that of $0 \%(\mathrm{AF} 0)$ and $50 \%(\mathrm{AF} 5)(\mathrm{p}<0.05)$. The HLI (WAC/OAC report) range from $1.38 \pm 0.01$ to $1.42 \pm$ 0.01 . The values of HLI are significantly identical for the formulations at $0 \%(\mathrm{AF} 0), 10 \%(\mathrm{AF} 1)$ and $50 \%$ (AF5). The BD decreases gradually as soybean increases. Values are significantly different and range from $0.87 \pm 0.00$ to $0.67 \pm 0.01 \mathrm{~g} / \mathrm{ml}$.

Tableau 3: Functional properties of "BASSI" based maize improved with soybean

\begin{tabular}{|c|cccccc|}
\hline Parameters & AF0 & AF1 & AF2 & AF3 & AF4 \\
\hline WAC* & $235.51^{\mathrm{a}} \pm 1.13$ & $239.87^{\mathrm{b}} \pm 0.60$ & $248.30^{\mathrm{c}} \pm 0.50$ & $252.88^{\mathrm{d}} \pm 0.32$ & $261.14^{\mathrm{e}} \pm 2.26$ & $268.41^{\mathrm{f}} \pm 1.19$ \\
OAC** & $168.45^{\mathrm{a}} \pm 1.31$ & $171.75^{\mathrm{b}} \pm 2.55$ & $175.57^{\mathrm{c}} \pm 1.10$ & $181.57^{\mathrm{d}} \pm 0.42$ & $189.09^{\mathrm{e}} \pm 0.50$ & $191.20^{\mathrm{f}} \pm 0.72$ \\
HLI & $1.40^{\mathrm{ab}} \pm 0.00$ & $1.40^{\mathrm{ab}} \pm 0.02$ & $1.42^{\mathrm{b}} \pm 0.01$ & $1.39^{\mathrm{a}} \pm 0.00$ & $1.38^{\mathrm{a}} \pm 0.01$ & $1.40^{\mathrm{ab}} \pm 0.01$ \\
EA (\%) & $52.67^{\mathrm{a}} \pm 1.01$ & $54.06^{\mathrm{b}} \pm 0.34$ & $55.97^{\mathrm{c}} \pm 0.62$ & $56.60^{\mathrm{d}} \pm 0.00$ & $57.33^{\mathrm{e}} \pm 0.62$ & $59.36^{\mathrm{f}} \pm 0.81$ \\
ES (\%) & $99.33^{\mathrm{c}} \pm 1.15$ & $96.77^{\mathrm{b}} \pm 0.10$ & $96.93^{\mathrm{b}} \pm 0.14$ & $96.77^{\mathrm{b}} \pm 0.00$ & $95.31^{\mathrm{b}} \pm 1.77$ & $89.09^{\mathrm{a}} \pm 1.44$ \\
BD (g/ml) & $0.87^{\mathrm{f}} \pm 0.00$ & $0.82^{\mathrm{e}} \pm 0.00$ & $0.79^{\mathrm{d}} \pm 0.00$ & $0.76^{\mathrm{c}} \pm 0.01$ & $0.72^{\mathrm{b}} \pm 0.02$ & $0.67^{\mathrm{a}} \pm 0.01$ \\
\hline
\end{tabular}

Values followed by different letters in a line are statistically different $(\alpha=0.05)$. Values represent the mean $\pm S D$ of three independent

measurements $(n=3) *($ Kcal/100 g of dry matter $)$.

\subsection{Discussion}

3.2.1. Chemical analysis of "BASSI" improved with soybean

The protein content of the formulations increases with soybean incorporation. This result is in agreement with those of Akubor and Onimawo (2003) and Akusu and Wordu (2013) in their studies on the functional properties of local products. The protein content $(10.91 \%)$ of AF2 formulation is lower than that found by Kalimbira et al. (2004) which obtained $14.15 \%$. This difference could be related to the maize variety used. According to Sanogo (1994) Codex Alimentarius recommends a minimum of $13 \%$ protein for infant foods. AF3, AF4 and AF5 formulations are in compliance with Codex recommendations. The fat content also increases with soybean incorporation because soybean is rich in fat. Maize flours are naturally low in fat $(3.08 \%$ for maize). Incorporation of soybean which is an oleaginous improves the fat content of the food. According to Demaison and Moreau (2002), the omega fats present in soybean are responsible for cardiovascular and immune balance. AF4 and AF5 formulations exceed the recommendations of the Codex Alimentarius (7\%) for baby food (Sanogo, 1994). The ash content reflects the mineral composition of a food. That of our formulations increases with soybean rate. The formulations (AF4, AF5) exceed the recommendations of Codex Alimentarius (2\%) for baby food (Sanogo, 1994). The results presented in tables 1 and 2 show that with the exception of calcium and copper (only for formulations containing millet), the mineral content of the formulations from 10 to $50 \%$ tend to satisfy the minimum desirable contents of an infantile flour (Mouquet et al., 1988). All formulations are 
excellent sources of carbohydrates. Formulations of 0 to $30 \%$ of soybean for both maize exceed the recommendations of the Codex Alimentarius (68\%) for baby food (Sanogo, 1994). The energy value increases as soybean increases. This could be attributed to high levels of fat content (Kalimbira et al., 2004). All formulations have energy values similar to the recommendations of Codex Alimentarius (400 Kcal/100 g of DM) for baby food (Sanogo, 1994). The $\mathrm{pH}$ values are statistically different while those of acidity are identical. These acidic $\mathrm{pH}$ values are beneficial for food, especially in infant food (Soro et al., 2013) as most enzyme reactions are favored in acidic media.

\subsubsection{Functional properties of "BASSI" improved with soybean}

The oil absorption capacity (WAC) provides information on the maximum amount of water absorbed by food (Siddiq et al., 2010). WAC of formulations increases with soybean rate. These results are consistent with the work of Akubor and Badifu (2004) which showed that increasing the WAC could be explained by the increase in protein content (many hydrophilic residues). WAC values for the formulations from 20 to $50 \%$ (248.30 to $268.41 \%$ for maize) are superior to those obtained by Akubor and Onimawo (2003) (180-190\%). High values of WAC can also be assigned to cooking effect. Cooking would lead to dissociation and modification of protein molecules in monomeric subunits that can retain more water in the binding sites as suggested by Lin et al. (1974). A high value of WAC of flour is an important property in pastry flour (Wolf, 1970).

The oil absorption capacity (OAC) is important for the development of flavor and food preservation, because it would prevent the development of oxidative rancidity in reducing the availability of oil for oxygen in food (Siddiq et al., 2010). In our study, the OAC increases with soybean incorporation. This increase is attributed to their protein content and the cooking effect as suggested by an author (El-Adawy, 2000). The type of protein can also influence oil retention properties, because the oil is attached to the nonpolar side chains of proteins as mentioned by some authors (Siddiq et al., 2010) in their work on the physical and functional characteristics of beans flour. The ability of proteins to retain oil is an interesting property because it allows good retention of flavor in the food processes, improving palatability (Moure et al., 2006). The flours of this study could be good lipophilic constituents and therefore suitable for preparing soups and cakes as shown by some authors (Aremu et al., 2007).

The hydrophilic-lipophilic index (HLI) assesses the comparative flour affinity for water and oil. The values for the formulations based on maize (1.38 and 1.42) are superior to those reported by Njintang et al. (2001) for cowpea (about 1.12). More HLI approach to value 1 , more the flour has good affinity for water as well as oil. All the values are greater than 1, this means that the flours have more affinity for water than oil.

The emulsifying activity (EA) is an important parameter in the development of formulations requiring mixtures of water and oil, such as baked goods (Shad et al., 2013). This parameter increases with soy incorporation. Improving the EA could be attributed to the increase in protein content as suggested by some authors (Moure et al., 2006). Soy protein helps the formation of emulsions and their stability during food processing. Our results agree with those of Siddiq et al. (2010) which reported in their study that the high stability of flour emulsion was due to the globular nature of the main soy proteins.

The bulk density (BD) is influenced by the size of the starch particles. The resulting values decrease as soybean increases. This could probably due to the fact that maize have higher densities than soybeans (Akubor and Onimawo, 2003). The same authors reported a similarity with the cookies made from soy flour and maize. This decrease may be also due to the small amount of starch in soya meal compared to maize. This property is important during mixing and packaging (Sakai, 1979).

\section{Conclusion and perspectives}

This study is a contribution for improving the nutritional quality and functional properties of "BASSI", a local product based on a mixture of maize and soybean. "BASSI" enrichment with soybean improves nutrient levels and functional properties of the formulations. "BASSI" consumption can reduce the risk of malnutrition among the population, particularly in children. The results for the functional properties provide useful data for their potential uses in food industry. In perspective, it would be interesting to determine the profiles of amino acids and fatty acids that are crucial for assessing the quality of protein and fat. In addition, the establishment of an extension policy is needed to bring the population to consume improved traditional dishes that meet the nutritional quality requirements.

\section{Acknowledgements}

The technical support of Laboratoire National de la Santé Publique (LNSP) is acknowledged. The author wishes to express sincere appreciation to Prof. Malan Kla Anglade for its technical comments and manuscript editing. 


\section{References}

1. Agbo NG. 1996. Supplementation of a traditional Ivoirian food (Attieke) with soybean. These de doctorat: Université de Cocody-Abidjan, p 15-20.

2. Akanvou L, Akanvou R, Anguété K, Diarrassouba L. 2006 Bien cultiver le maïs en Côte d'Ivoire. Centre National de Recherche Agronomique (CNRA); 4 p.

3. Akubor PI, Onimawo, IA. 2003. Functional properties and performance of soybean and maize flour blends in cookies. Plant Foods Hum. Nutr. 58:1-12.

4. Akubor PI, Badifu GIO. 2004. Chemical composition, functional properties and baking potentiel of African breadfruit kernel and wheat flour blends. Int. J. Food Sci. Technol. 39:223-9.

5. Akusu MO, Wordu GO. 2013. Nutritional and sensory evaluation of EPITI (IKWOKE) prepared from maize/soybean flour blends. Int. J. Sci. Emerg. Technol. 6(3):230-5

6. AOAC. 1990. Official methods of analysis, 15th Eds, Washington, $774 \mathrm{p}$

7. Aremu MO, Olonisakin A, Atolaye BO, Ogbu CF. 2007. Some nutritional composition and functional properties of Prosopis Africana. Bangladesh J. Sci. Ind. Res. 42 (3):26980.

8. Atwater WO, Benedict FG. 1902. Experiments on the metabolism of matter and energy in the human body. Bulletin $\mathrm{N}^{\circ}$ 109, Washington DC

9. Bekoye BM, Akanvou R. 2005. Bien cultiver le mil en Côte d'Ivoire. Centre National de Recherche Agronomique (CNRA); $4 \mathrm{p}$

10. Demaison L, Moreau D. 2002. Dietary n-3 polyunsatured fatty acids and coronary heart disease-related mortality: a possible mechanism of action. Cell. Molecul. Life Sci. 5:46377.

11. Duc G, Mignolet C, Carrouée B, Huyghe C. 2010.

Importance économique passée et présente des légumineuses : rôle historique dans les assolements et facteurs d'évolution. Innov. Agronom. 11:1-24.

12. El-Adawy TA. 2000. Functional properties and nutritional quality of acetylated and succinylated mung bean protein isolate. Food Chem. 70 (1):83-91

13. FAO. 1995. Le sorgho et les mils dans l'alimentation humaine. http://www.fao.org/docrep/t0818f/t0818f01.htm $(15 / 01 / 2016)$

14. FAO. 2009. La situation mondiale de l'alimentation et l'agriculture. http://www.fao.org/datalog/Inter.htm $(15 / 01 / 2016)$

15. Folch J, Lees M, Stanley GHS. 1957. A simple method for the isolation and purification of total lipids from animal tissues. J. Biol. Chem. 172:497-509.

16. Kalimbira AA, Mtimuni BM, Mtimuni JP. 2004. Effect of incorporating legumes on nutritive value of cassava-based complementary foods. J. Agric. Environ. Sci. Technol. 2:1321.

17. Lin MJY, Humbert ES, Sosulski FW. 1974. Certain functional properties of sunflower meal products. J. Food Sci. 39:368-71.

18. Mouquet C, Bruyeron O, Trèche S. 1998. Les farines infantiles : Caractéristiques d'une bonne farine infantile. Bull. Res. TPA 15:11.

19. Moure A, Sineiro J, Dominiguez H, Parajo J.C. 2006 Functionality of oil seed protein product: a review. Food Res. Int. 38:945-63.

20. Narayana K, Narasimga RNMS. 1982. Functional properties of raw and heat processed winged bean flour. J. Food Sci. 47:1534-38

21. Njintang NY, Mbofung CMF, Waldron KW. 2001. In vitro protein digestibility and physicochemical properties of dry red bean (Phaseolus vulgaris) flour: effect of processing and incorporation of soybean and cowpea flour. J. Agri. Food Chem. 49:2465-71.

22. Phillips RD, Chinnan MS, Branch AL, Miller J, Mcwatters KH. 1988. Effects of pre-treatment on functional and nutritional properties of cowpea meal. J. Food Sci. 3:805-9.

23. Sakai WS. 1979. Aroid root crop In: Tropical Foods, Chem. Nutr., NewYork 1, p 268.

24. Sanogo M. 1994. La production artisanale de farines infantiles. Editions du GRET, Paris, 79 p.

25. Shad MA, Nawaz H, Noor M, Ahmad HB, Hussain M, Choudhry MA. 2013. Functional properties of maize flour and its blends with wheat flour: optimization of preparation conditions by response surface methodology. Pakistan J. Botany 45(6):2027-35.

26. Siddiq M, Rav R, Harte JB, Dolan KD. 2010. Physical and functional characteristics of selected dry bean (Phaseolus vulgaricus (L.) flours. J. Food Sci. Technol. 43:232-7.

27. Soro S, Konan G, Elleingand E, N'guessan D, Koffi E. 2013 Formulation d'aliments infantiles à base de farines d'igname enrichies au soja. Afr. J. Food Agric. Nutr. Dev. 13(5):8313 39

28. Sosulski FW. 1962. The centrifuge method for determining flour absorption in hard red spring wheat. Cereal Chem. 39:344-50.

29. Wolf WJ. 1970. Soybean proteins: their functional, chemica and physical properties. J. Agric. Food Chem. 18:965-9.

30. Yasumatsu K, Sawada K, Moritaka S, Misaki M, Tuda J, Wada T, Ishii K. 1972. Whipping and emulsifying properties of soybean products. Agri. Biol. Chem. 36:716-27.

31. Zannou-Tchoko JV, Ahui-Bitty BL, Kouame K, Bouaffou MGK, Dally T. 2011. Utilisation de la farine de maïs germe source d'alpha amylases pour augmenter la densité énergétique de bouillies de sevrage à base de manioc et son dérivé l'attiéké. J. Appl. Biosci. 37:2477-84. 